\title{
Social Network Sites in Businesses: Combating Technostress
}

\author{
Murad Moqbel \\ University of Oklahoma \\ mmoqbel@ou.edu
}

\author{
Valerie L. Bartelt \\ University of Denver \\ Valerie.Bartelt@du.edu
}

\begin{abstract}
This survey research examined social networking sites (SNS) internal to the company to determine how SNS use affects attitudes, and ultimately turnover intentions. We hypothesize that due to social capital, emotional dissonance, and conservation of resource theories, work SNS use will decrease work isolation, which will decrease work-related attitudes and increase turnover intentions. Due to social capital theory, we propose that work SNS use will decrease work isolation. Due to emotional dissonance theory, we hypothesize that work isolation will decrease positive emotions and job satisfaction, and increase job tensions, such as work stress. All three of these factors will increase turnover intentions. These findings suggest that technology has the potential of reducing technostress symptoms at work. We found that incorporating internal SNS in businesses improves attitudes and behaviors, which is important for managers to consider as ways to save costs due to employee turnover.
\end{abstract}

\section{Introduction}

Prior research has identified stress related to IT work as affecting a variety of attitudes and behaviors, including organizational commitment and turnover intentions [1, 2]. Due to increased competition, businesses are rewarding employees who work long hours $[2,3,4]$. This research explores whether stress (work stress, in particular), due to SNS internal to businesses negatively affects attitudes and behaviors at work - including antisocial behavior (workplace isolation), positive emotions, and turnover intentions. This paper uses social capital theory, emotional dissonance theory [5], and conservation of resources theory [6] as underlying frameworks. Interestingly, we found that SNS use in businesses decreased social isolation, and therefore improved work attitudes and behaviors. We are interested in whether behaviors and attitudes are improved when using SNS that is internal to the company. Prior research found social media use to improve performance $[7,8]$, although no research to our knowledge has determined whether internal SNS use in businesses decreases turnover intentions. Our findings may offer insights to managers for determining situations where introducing internal SNS might increase employees' job satisfaction and decrease turnover intentions.

\section{Research background and hypotheses}

\subsection{Social Networking Sites}

Social networking sites (SNS), such as Facebook and LinkedIn, are growing increasingly popular [9]. SNS are a web-based service that enable individuals to share profiles and content with each other $[9,10]$. Often, SNS are used on a daily basis [9].

SNS have been found to improve personal life behaviors and attitudes [11, 12], including increasing optimism and better coping skills [11]. Prior research has examined how weak and strong social networks play a role at work, determining that weak social networks lead to negative work-related behaviors such as turnover intentions [13]. We are not aware of prior research that has explored how SNS affects work attitudes, such as job satisfaction, positive emotions, and work stressors, ultimately leading to turnover intentions.

\subsection{Social Capital Theory and Work Isolation}

Social capital leverages resources gained through a network, that could be virtual or actual $[10,14]$. Resources gained from social capital include a "network of ties of goodwill, mutual support, shared language, shared norms, social trust, and a sense of mutual obligation that people can derive value from," $[10,15]$. A variety of disciplines have used social capital in prior research $[10,16]$.

Three general dimensions of social capital includes structural, cognitive, and relational [17]. The structural dimension includes patterns of connections, such as social ties and network structure [17]. The cognitive dimension are generally the resources that are obtained through shared interpretations [17]. The relational dimension are assets gained due to social connections [17]. Some public benefits obtained through social capital include facilitating collective action [18]. Private benefits involve increased access to resources and relationships $[10,19,20,21]$. Our 
paper is primarily interested in determining private benefits associated with work SNS use.

We believe that employees' use of SNS will naturally increase their access to social capital, including increased access to resources and relationships. This increased social capital gained through internal SNS use will result in the employee feeling more of a part of the work community, especially due to greater social ties [17] and social support [22, 23, 24]. Increased social capital through internal SNS use will naturally decrease an employee's feelings of isolation. Thus, we hypothesize that due to increased social capital experienced by employees from using SNS, work isolation will decrease.

H1: Work-Related SNS Use decreases work isolation.

\subsection{Emotional Dissonance and the Work Environment}

Emotional dissonance is a conflict between the work experience and a person's emotional state of mind [5]. This potential clash between a person's emotions and organizational norms $[5,25]$ can create a person-role conflict $[5,26]$. Employees who comply with the organization will experience conflicting feelings [5] in the situation where they do not want to comply. Thus, emotional dissonance has been found to decrease job satisfaction [5]. Typically, a person who experiences any type of emotional or cognitive dissonance prefers to resolve this dissonance so they can return to a more harmonious state [27].

Work isolation involves two components: 1) perceptions of isolation from colleagues and 2) perceptions of isolation from a business' support network [28], which could both result in negative perceptions towards work [29]. We are interested in the perceptions of work isolation from a business' support network, which could be due to working extended hours at home and therefore away from the business' support network.

Due to emotional dissonance, we believe that a person desires to keep similar mindsets of either harmony or disharmony between their organizational experience and emotional state [5], which will result in both their emotional and organizational experience in being either positive or negative based on which mindset dominates. Because work isolation often leads to negative attitudes towards work [29] due to perceived isolation from a business' support network, we believe that employees' emotions towards the work environment will become more negative in order to resolve emotional dissonance experiences. Thus, work isolation will decrease positive emotions.

\section{H2: Work isolation decreases positive emotions.}

Similarly, emotional dissonance has been identified when employees are dissatisfied with their job [5]. The disconnect between an employee's emotional state based on potential compromised values at work or the inability of the business to meet expectations are some examples that could cause emotional dissonance $[5,30]$. In this research, we believe that work isolation may cause an employee to be in conflict with any positive emotions he/she may be experiencing towards work, especially since this has also been found in prior research [29]. Because of a person's preference to minimize dissonant experiences, we believe that work isolation will result in a person's emotions towards the organization to be negatively affected $(\mathrm{H} 2)$, and thus due to emotional dissonance of keeping in similar states of mind, work isolation experiences will decrease employees' experience of work satisfaction.

\section{H3: Work isolation decreases work satisfaction.}

\subsection{Work Stress, Work Isolation, and Emotions}

Work stress involves perceptions that situations in a business environment are difficult or challenging, which threatens a person's wellbeing [31]. Work stress has been found to cause organizational issues, including increased burnout and turnover intentions [31].

As discussed in the prior hypothesis, emotional dissonance may be experienced at work due to a conflict in employees' emotional state and their work experiences [5, 30]. It therefore follows that if employees experience work isolation where they feel disconnected from their support network, their experiences towards work will become more negative in their attempt to remain in harmony between their emotional state and work experiences. As a result, employees' perceptions of having a more challenging work environment will increase. Thus, we believe that work isolation will increase work stress.

\section{H4: Work isolation positively affects work stress.}

Since emotional dissonance can be experienced when there is a disconnect between the feelings towards the organization and an employee's personal emotions, we believe that positive emotions will cause an employee's experience towards an organization to be more positive, thereby lessening perceptions of potentially difficult work situations. Again, this is due to a person desiring to minimize dissonant experiences/feelings [27]. Thus, employees' positive emotions will decrease their work stress. 


\section{H5: Positive emotions decreases work stress.}

Similar to H5, emotional dissonance is the disconnect between the person's positive emotions and their organizational experiences. A person prefers to remedy this dissonance in order to experience more harmonious situations [27]. Thus, employees' positive emotions will increase their positive organizational attitudes, such as job satisfaction.

H6: Positive emotions increases job satisfaction.

\subsection{Conservation of Resources and Work Stress}

Conservation of Resources theory involves people working towards their values, or resources, such as money, work-life-balance, and a successful career [6]. When these resources are lost, or threatened, then stress results and physical and emotional exhaustion ensues [6], which has been found to increase turnover intentions [1]. We similarly hypothesize that due to the Conservation of Resources theory, work stress, which often involves a challenging work environment [31], causes resources to be lost - such as resources supporting an optimal work-life balance. We hypothesize that these lost resources will increase turnover intentions due to employees choosing to leave their current challenging situation for a better work environment where their lost resources can be gained.

H7: Work stress increases turnover intentions.

\subsection{Job Dis/satisfaction, Positive Emotions and Turnover Intentions}

Job dissatisfaction involves a negative emotional state due to compromised personal values compared to the organization $[5,30]$. Job satisfaction and job stress have been identified as having an inverse relationship $[32,33,34]$. According to models from prior research, job dissatisfaction conjures thoughts of termination [5, 35]. Prior research has found job satisfaction to be an antecedent of turnover intentions [5, 36, 37, 38, 39]. To resolve feelings of emotional dissonance towards the organization, we believe that a positive mindset associated with job satisfaction will lessen the more negative mindset of desiring to leave a job, thereby decreasing turnover intentions.

H8: Job satisfaction decreases turnover intentions.

Conversely, due to emotional dissonance, positive emotions encourage employees' perspective of an organization to be more favorable. This is due to employees preferring to minimize conflicting dissonant feelings [27] that may be associated with turnover intentions. Thus, we believe that positive emotions will decrease negative organizational attitudes, such as turnover intentions.

H9: Positive emotions decreases turnover intentions.

\section{Research Methodology}

To examined our research model and hypotheses, we undertook an online survey at an information technology corporation in the Midwest region of the U.S. which has more than 22,000 employees and serves more than 18,000 organizations around the world.

The ESM software platform consists of a suite of applications including social networking, wikis, blogs, document management, discussion forums, and search capabilities to find experts - capabilities that allow employees communicate, collaborate, innovate, and learn from one another.

\subsection{Respondents}

Of the 10,000 ones sent out, 320 surveys were obtained, of which 276 were fully completed, yielding an effective response rate of $3.2 \%$. The low response rate was comparable to similar studies [40]. To mitigate non-response bias, we took a priori measures to reduce non-responses including offering a drawing for participation, stressing anonymity, and emphasizing academia sponsorship, as recommended in the literature. None response bias was also assessed post hoc by comparing the first third of responses and the third portion of responses finding no significant differences between the two groups. Therefore, nonresponse bias was ruled out as an issue in this study.

The average participant's age was 35.6 with 11.5 standard deviation. Females constituted 51.8\% ( $\mathrm{n}=$ 143) of the respondents. Participants' average tenure was 5.9 years. Of the participants, $4 \%$ had high school diplomas, $7 \%$ had associate degrees, 62\% had bachelor degrees, $26 \%$ had master's degrees, and $1.5 \%$ had doctoral degrees. ESM platform was used on average for approximately 1 hour and 43 minutes per day.

\subsection{Measures}

All the measures in this study are based on previously validated measures. The measure of ESM 
use was adopted from [41]. Work isolation was measured with items used by [28] and [29]. Positive emotions were measured with items from [42] and [43]. Work stress was measured with items from [44] and [45]. Job satisfaction measure was adapted from [46] and [47]. Turnover intentions measure was adopted from [47]. Age, exercise, gender, education level, race and tenure were included as control variables.

We undertook a PLS-based structural equation modeling (SEM) data analysis approach [48, 49] to assess the psychometric properties of the measurement instrument. All constructs in this study were assessed in terms of reliability, convergent validity, and discriminant validity using the software WarpPLS 5.0 [50]. Reliability was assessed using composite reliability in which all values exceeded the suggested threshold of 0.7 [48] and therefore met this criterion. For convergent validity, all item loadings exceeded the suggested threshold of 0.6 [51], indicating acceptable convergent validity. Table 1 shows that all measures have good reliability and validity.

Table 1. Construct Reliability and Validity

\begin{tabular}{|c|c|c|c|c|c|c|}
\hline Constructs & Item & Loading & CR & CA & FVIF & Nor \\
\hline \multirow{5}{*}{$\begin{array}{l}\text { SNS Work } \\
\text { Use }\end{array}$} & SNSUse1 & $(0.798)$ & \multirow{5}{*}{0.88} & \multirow{5}{*}{0.83} & \multirow{5}{*}{1.23} & No \\
\hline & SNSUse2 & (0.669) & & & & \\
\hline & SNSUse3 & $(0.814)$ & & & & \\
\hline & SNSUse4 & $(0.722)$ & & & & \\
\hline & SNSUse5 & $(0.828)$ & & & & \\
\hline \multirow{3}{*}{$\begin{array}{l}\text { Workplace } \\
\text { Isolation }\end{array}$} & WIso1 & $(0.805)$ & \multirow{3}{*}{0.86} & \multirow{3}{*}{0.77} & \multirow{3}{*}{1.41} & No \\
\hline & WIso2 & $(0.834)$ & & & & \\
\hline & WIso3 & $(0.833)$ & & & & \\
\hline \multirow{3}{*}{$\begin{array}{l}\text { Job } \\
\text { Satisfaction }\end{array}$} & JobSat1 & $(0.956)$ & \multirow{3}{*}{0.98} & \multirow{3}{*}{0.96} & \multirow{3}{*}{1.73} & No \\
\hline & JobSat2 & $(0.974)$ & & & & \\
\hline & JobSat3 & $(0.964)$ & & & & \\
\hline \multirow{7}{*}{$\begin{array}{l}\text { Positive } \\
\text { emotions }\end{array}$} & PosEmo1 & $(0.822)$ & \multirow{7}{*}{0.94} & \multirow{7}{*}{0.92} & \multirow{7}{*}{1.25} & Yes \\
\hline & PosEmo2 & (0.899) & & & & \\
\hline & PosEmo3 & $(0.787)$ & & & & \\
\hline & PosEmo4 & $(0.734)$ & & & & \\
\hline & PosEmo5 & $(0.854)$ & & & & \\
\hline & PosEmo6 & $(0.815)$ & & & & \\
\hline & PosEmo7 & $(0.850)$ & & & & \\
\hline \multirow{5}{*}{ Work Stress } & Stress1 & $(0.700)$ & \multirow{5}{*}{0.89} & \multirow{5}{*}{0.85} & \multirow{5}{*}{1.25} & No \\
\hline & Stress2 & $(0.862)$ & & & & \\
\hline & Stress3 & $(0.812)$ & & & & \\
\hline & Stress4 & $(0.832)$ & & & & \\
\hline & Stress5 & $(0.737)$ & & & & \\
\hline
\end{tabular}

Notes: All loadings significant at the $\mathrm{p}<0.001 ; \mathrm{CR}=$ composite reliability; $\mathrm{CA}=$ Cronbach's alpha; FVIF = full collinearity variance information factor; Nor= normal (robust Jarque-Bera). SNSUse $=$ social networking work use; WIso = workplace isolation with the company; JobSat = job satisfaction; PosEmo $=$ positive emotions; Stress $=$ work stress.

Discriminant validity was examined employing criteria suggested by [52] in which the square room of the average variance extracted (AVE) should be greater than the inter-construct correlations. Table 2 shows that the AVEs are greater than the interconstruct correlations providing evidence of discriminant validity.

Table 2. Inter-construct Correlation Matrix

\begin{tabular}{lrrrrr} 
& SNSUse & WIso & JobSat & PosEmo & Stress \\
\hline SNSUse & $(0.769)$ & & & & \\
WIso & -0.324 & $(0.824)$ & & & \\
JobSat & 0.155 & -0.351 & $(0.965)$ & & \\
PosEmo & -0.002 & -0.146 & 0.325 & $(0.824)$ & \\
Stress & 0.039 & 0.129 & -0.231 & -0.044 & $(0.791)$
\end{tabular}

Notes: Square roots of average variances extracted (AVE) shown on the diagonal within parentheses; SNSUse = social networking work use; WIso $=$ workplace isolation with the company; JobSat $=$ job satisfaction $;$ PosEmo $=$ positive emotions; Stress $=$ work stress.

Multicollinearity was evaluated by calculating the variance inflation factor (VIF). Table 1 shows that VIFs are all less than the recommended threshold of 5 [53], ruling out multi-collinearity as a concern in this study. We also assessed multivariate normality as suggested by [54] and [55] in Table 1 which shows that a few of the constructs did not meet the normal criteria justifying the use of PLS-based SEM.

\section{Results}

To test our structural model, standardized path coefficients were reports along with the explanatory power $-\mathrm{R}^{2}$. Figure 1 shows that all nine hypotheses were supported. The proposed model explains $44 \%$ of the variance in turnover intentions, $21 \%$ in job satisfaction, $4 \%$ in positive emotions, $10 \%$ in work stress, and $12 \%$ in work isolation.

SNS work use had significant impact on work isolation $(\mathrm{H} 1)(\beta=.35, \mathrm{p}<.001)$. Work Isolation had significant effects on positive emotions $(\mathrm{H} 2)(\beta=-.20$, $\mathrm{p}<.001)$, job satisfaction $(\mathrm{H} 3)(\beta=-.31, \mathrm{p}<.001)$, and work stress $(\mathrm{H} 4)(\beta=.22, \mathrm{p}<.001)$. Positive emotions had significant effects on work stress $(\mathrm{H} 5)(\beta=-.21, \mathrm{p}$ $<.001)$ and job satisfaction (H6) $(\beta=.29, \mathrm{p}<.001)$. Work stress $(\mathrm{H} 7)(\beta=.21, \mathrm{p}<.001)$, job satisfaction (H8) $(\beta=-.45, p<.001)$, and positive emotions (H9) $(\beta=-.16, p<.01)$ had significant effects on turnover intentions. Only exercise and age of all control variables were significant indicating that older employees $(\beta=.11, p<.05)$ intend to leave while those who exercise $(\beta=-.14, p<.01)$ tend to want to stay. 


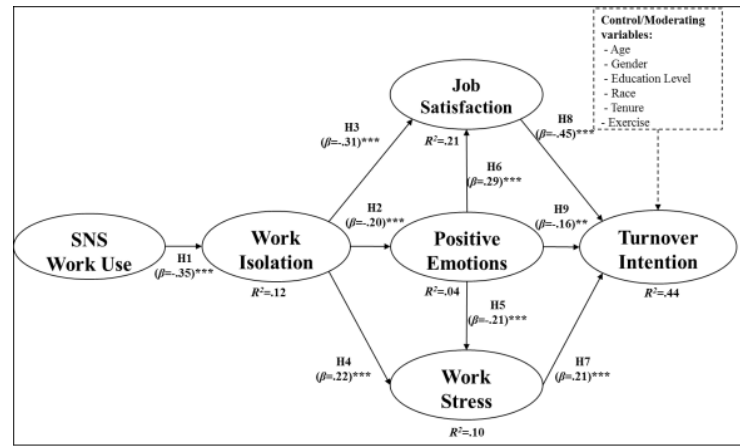

Notes: * $\mathrm{P}<0.05 ; * * \mathrm{P}<0.01 ; * * * \mathrm{P}<0.001$.

Figure 1: Hypotheses with related coefficients

\section{Discussions and Conclusions}

This research examined how SNS used for business purposes diminished antisocial behaviors, such as work isolation, which, in turn, decreased positive emotions, increased work stress, job dissatisfaction, and increased turnover intentions. We believe that technostress may be the underlying culprit for these negative work attitudes and behaviors, and we believe that, unlike other ICT, SNS helps to overcome technostress.

Technostress explains a person's inability to healthily interact with ICTs [58]. In today's modern society, work-life balance problems are abundant due to undue stress and its consequences [2, 56, 57], which is often due to ICT use [58]. Interestingly, more physical risks due to ICT use have been expressed than psychosocial risks [2]. ICTs have increased expectations to extend work life beyond the typical 9am-5pm work day [2, 59], increasing technostress symptoms [2]. It is a misperception that since ICT use in businesses helps productivity, then all is well [2]. There are many unintended consequences to ICT use that inhibit work performance [2]. In particular, having ubiquitous access to email on mobile devices have been found to cause stress and antisocial behavior [2], $[60,61]$.

SNS had been found in prior research to cultivate positive personal life attitudes and behaviors [11], [12]. Similarly, our research found that when SNS is used for work-related tasks, technostress antisocial behaviors [2, 60, 61], such as work isolation, decreases. Work isolation should be minimized in businesses, because this was found to negatively affect a person's positive emotions, work satisfaction, and increased work stress, ultimately leading to turnover intentions.

We found positive emotions to decrease work stress and increase job satisfaction, due to emotional dissonance. Because people prefer their emotional state to match their organizational experience, positive emotions improved work stress and job satisfaction. Job satisfaction was found to decrease turnover intentions, similarly due to emotional dissonance. However, work stress increased turnover intentions due to the conservation of resources theory. People possess limited resources and if they lose a particular resource, such as free time due to work stress, this may cause other resources to disappear, such work-lifebalance. As a result, employees may seek employment elsewhere.

\subsection{Managerial Implications}

According to the findings in this research, managers should proactively find ways to increase positive emotions and job satisfaction at work, since these decrease work stress and turnover intentions. Our research found that using SNS for work-related purposes decreased work isolation, and therefore increased positive emotions, work satisfaction, and decreased work stress - leading to increased turnover intentions. Thus, internal SNS in businesses may be a preferred technology for managers to consider incorporating. Since technostress is a common issue with ICT use [58], it is possible that overuse of work SNS could trigger this, so managers should consider limiting SNS use to business hours. Both managers and businesses should consider introducing SNS as a way to improve employee satisfaction. This may also save businesses money down the road by reducing healthcare costs that may result from unhappy employees, as well as reduce costs involved in training a new employee due to reduced turnover intentions. If employees stay longer, hopefully this will reduce the costs involved in hiring and training new employees over time.

\subsection{Further Research and Limitation}

Further research is needed to determine the ideal amount of time sufficient for work SNS to have a positive impact on employees. Also, further research would be helpful to determine the degree that nonwork related SNS activities improve business performance. This may include having users choose different affinity groups, not based on work specialties but based on hobbies or other non-work-related tasks. Although we have employed a priori and post hoc measures to mitigate non-response bias, low response bias is one of the limitations in this study. Therefore, future research should try other measures to improve response bias. In addition, it would be interesting to explore how different technology components within the software package may affect business outcomes. Prior research has found social-related SNS to improve personal attitudes and behaviors $[11,12]$, and 
thus it would be interesting to determine if similar attitudes and behaviors would take place in businesses.

\section{Conclusion}

Internal social networking sites (SNS) provided by businesses were found to improve attitudes and behaviors and decreased turnover intentions. Social capital theory, emotional dissonance, and conservation of resource were underlying theories used to support our hypotheses. Internal SNS in businesses decreased work isolation. Work isolation decreased positive emotions and job satisfaction, and increased work stress. Positive emotions and job satisfaction decreased turnover intentions while work stress increased it. These findings were important for determining whether it is beneficial to incorporate internal SNS in businesses.

\section{References}

[1] M.K. Ahuja, K.M. Chudoba, C.J. Kacmar, D.H. McKnight, J.F. and George, "IT Road Warriors: Balancing Work-Family Conflict, Job Autonomy, and Work Overload to Mitigate Turnover Intentions", MIS Quarterly, 2007, pp.1-17.

[2] R. Ayyagari, V. Grover, and R. Purvis, "Technostress: Technological Antecedents and Implications", MIS Quarterly, 2011, pp. 831-858

[3] A. Kouzmin, and N. Korac-Kakabadse, "Mapping Institutional Impacts of Lean Communication in Lean Agencies: Information Technology Illiteracy and Leadership Failure", Administration \& Society, 2000, pp.29-69.

[4] G. Spruell, "Work fever", Training \& Development Journal, 1987.

[5] R. Abraham, "The Impact of Emotional Dissonance on Organizational Commitment and Intention to Turnover", The Journal of Psychology, 1999, pp.441-455.

[6] S.E. Hobfoll, and J. Freedy, "Conservation of Resources: A General Stress Theory Applied to Burnout", 1993.

[7] H. Ali-Hassan, D. Nevo, and M. Wade. "Linking Dimensions of Social Media Use to Job Performance: The Role of Social Capital", The Journal of Strategic Information Systems, 2015, pp. 65-89.

[8] Y. Gao, Yang, X. Zhang, A. Chen, Y. Sun, and R. Zhang. "Adapt to Changes or Not? The Mediating Effect of Individual Adaptability between Social Media and Task Performance", System Sciences (HICSS), 49th Hawaii International Conference on. IEEE, 2016, pp. 2126-2135.
[9] D.M. Boyd, and N.B. Ellison, "Social Network Sites: Definition, History, and Scholarship", Journal of Computer-Mediated Communication, 2008, pp. 210-230.

[10] N. Ellison, R. Heino, and J. Gibbs, "Managing Impressions Online: Self-Presentation Processes in the Online Dating Environment", Journal of ComputerMediated Communication, 2006, pp. 415-441.

[11] I. Brissette, M.F. Scheier, and C.S. Carver, "The Role of Optimism in Social Network Development, Coping, and Psychological Adjustment during a Life Transition", Journal of Personality and Social Psychology, 2002, p. 102.

[12] C. Steinfield, N.B. Ellison, and C. Lampe, "Social Capital, Self-Esteem, and Use of Online Social Network Sites: A Longitudinal Analysis", Journal of Applied Developmental Psychology, 2008, pp.434-445.

[13] D.P. Moynihan, and S.K. Pandey, "The Role of Organizations in Fostering Public Service Motivation", Public Administration Review, 2007, pp.40-53.

[14] Bourdieu, P., and L. Wacquant, An invitation to reflexive sociology, University of Chicago Press, Chicago, 1992.

[15] M. Huysman, and V. Wulf, "Social Capital and Information Technology: Current Debates and Research", Social Capital and Information Technology, 2004, pp. 1-15.

[16] P.S. Adler, and S. Kwon, "Social Capital: Prospects for a New Concept", Academy of Management Review, 2002, pp. 17-40.

[17] J. Nahapiet, and G. Sumantra, "Social Capital, Intellectual Capital and the Creation of Value in Firms", Academy of Management Proceedings, Academy of Management, 1997.

[18] F. Requena, "Social Capital, Satisfaction and Quality of Life in the Workplace", Social Indicators Research, 2003, pp. 331-360.

[19] R.S. Burt, "The Contingent Value of Social Capital", Administrative Science Quarterly, 1997, pp. 339-365.

[20] R.S. Burt, "Structural Holes and Good Ideas 1", American Journal of Sociology, 2004, pp. 349-399.

[21] P. Paxton, "Is Social Capital Declining in the United States? A Multiple Indicator Assessment 1", American Journal of Sociology, 1999, pp. 88-127.

[22] N.B. Ellison, C. Steinfield, and C. Lampe, "The Benefits of Facebook "Friends:" Social Capital and College Students' Use of Online Social Network Sites", Journal of Computer-Mediated Communication, 2007, pp. 1143-1168. 
[23] M. Moqbel. "The Effect of the Use of Social Networking Sites in the Workplace on Job Performance", Diss. Texas A\&M International University, 2012.

[24] R.D. Putnam, "Bowling Alone: America's Declining Social Capital", In Culture and Politics, Palgrave Macmillan, US, 2000, pp. 223-234.

[25] A. Rafaeli, and R.I. Sutton, "Expression of emotion as part of the work role", Academy of Management Review, 1987, pp. 23-37.

[26] R. L. Kahn, D.M. Wolfe, R.P. Quinn, J.D. Snoek, and R.A. Rosenthal, "Organizational Stress: Studies in Role Conflict and Ambiguity", 1964.

[27] L. Festinger, "Cognitive Dissonance", Scientific American, 1962.

[28] G.W. Marshall, C.E. Michaels, and J.P. Mulki, "Workplace Isolation: Exploring the Construct and Its Measurement", Psychology \& Marketing, 2007, pp. 195223.

[29] J.P. Mulki, and F. Jaramillo, "Workplace Isolation: Salespeople and Supervisors in USA", International Journal of Human Resource Management, 2011, pp. 902-923.

[30] L.W. Porter, and E.E. Lawler, "Managerial Attitudes and Performance", 1968.

[31] A.S. Bell, D. Rajendran, and S. Theiler, "Job Stress, Wellbeing, Work-Life Balance and Work-Life Conflict among Australian Academics", Sensoria: A Journal Of Mind, Brain \& Culture, 2012, pp. 25-37.

[32] C.J. Hollon, and R.J. Chesser, "The Relationship of Personal Influence Dissonance to Job Tension, Satisfaction and Involvement", Academy of Management Journal, 1976, pp. 308-314.

[33] R.H. Miles, and M.M. Petty, "Relationships between Role Clarity, Neet for Clarity, and Job Tension and Satisfaction for Supervisory and Nonsupervisory Roles", Academy of Management Journal, 1975, pp. 877-883.

[34] S.E. Sullivan, and R.S. Bhagat, "Organizational Stress, Job Satisfaction, and Job Performance: Where do we go from Here?", Journal of Management, 1992, pp. 353-374.

[35] W.H. Mobley, "Intermediate Linkages in the Relationship between Job Satisfaction and Employee Turnover", Journal of Applied Psychology, 1977, p. 237.

[36] A.H. Brayfield, and W.H. Crockett, "Employee Attitudes and Employee Performance", Psychological Bulletin, 1955, p. 396.

[37] F. Herzberg, B. Mausnes, R.O. Peterson, and D.F. Capwell, "Job Attitudes", Review of Research and Opinion, 1957.
[38] E.A. Locke, "Personnel Attitudes and Motivation", Annual Review of Psychology, 1975, pp.457-480.

[39] L.W. Porter, and R.M. Steers, "Organizational, Work, and Personal Factors in Employee Turnover and Absenteeism”, Psychological Bulletin, 1973, p. 151.

[40] S.A. Sivo, C. Saunders, Q. Chang, and J.J. Jiang, "How Low Should You Go? Low Response Rates and the Validity of Inference in Is Questionnaire Research", Journal of the Association for Information Systems, 2006, pp. 351-415.

[41] E. Gonzalez, D. Leidner, C. Riemenschneider, and H. Koch, "The Impact of Internal Social Media Usage on Organizational Socialization and Commitment", Thirty Fourth International Conference on Information Systems, Milan, Italy, 2013, pp. 1-18.

[42] E. Diener, H. Smith, and F. Fujita, "The Personality Structure of Affect", Journal of Personality and Social Psychology, 1995, p. 130.

[43] R.E. Lucas, E. Diener, and R.J. Larsen, Positive Psychological Assessment: A Handbook of Models and Measures. American Psychological Association, Washington, DC, US, 2003.

[44] A.S. Bell, D. Rajendran, and S. Theiler, "Job Stress, Wellbeing, Work-Life Balance and Work-Life Conflict among Australian Academics", Sensoria: A Journal Of Mind, Brain \& Culture, 2012, pp. 25-37.

[45] J.M. Stanton, W.K. Balzer, P.C. Smith, L.F. Parra, and G. Ironson, "A General Measure of Work Stress: The Stress in General Scale," Educational And Psychological Measurement, 2001, pp. 866-888.

[46] M. Moqbel, S. Nevo, and N. Kock. "Organizational Members' Use of Social Networking Sites and Job Performance: An Exploratory Study", Information Technology \& People, 2013, pp. 240-264.

[47] P.E. Spector, "Measurement of Human Service Staff Satisfaction: Development of the Job Satisfaction Survey", American Journal of Community Psychology, 1985, pp. 693-713.

[48] W.W. Chin, "The Partial Least Squares Approach to Structural Equation Modeling", Modern Methods for Business Research, 1998, pp. 295-336.

[49] M. Haenlein, and A.M. Kaplan. "A Beginner's Guide to Partial Least Squares Analysis", Understanding Statistics, 2004, pp. 283-297.

[50] N. Kock, "Common Method Bias in PLS-SEM: A Full Collinearity Assessment Approach", International Journal of e-Collaboration, 2015, pp. 1-10.

[51] D. Gefen, and S. Detmar, "A Practical Guide to Factorial Validity using PLS-Graph: Tutorial and 
Annotated Example", Communications of the Association for Information Systems, 2005, p. 5.

[52] C. Fornell, and D.F. Larcker. "Structural Equation Models with Unobservable Variables and Measurement Error: Algebra and Statistics", Journal of Marketing Research, 1981, pp. 382-388.

[53] J. Hair, W. Black, B. Babin, and R. Anderson. Multivariate Data Analysis. Pearson, Upper Saddle River, N.J.; London, 2010.

[54] A.K. Bera, and C.M. Jarque, "Efficient Tests for Normality, Homoscedasticity and Serial Independence of Regression Residuals: Monte Carlo Evidence", Economics Letters, 1981, pp. 313-318.

[55] Y.R. Gel, and J.L. Gastwirth. "A Robust Modification of the Jarque-Bera Test of Normality", Economics Letters, 2008, pp. 30-32.

[56] V.J. Sutherland, and C.L. Cooper, "Understanding Stress: A Psychological Perspective for Health Professionals", Chapman \& Hall/CRC, 1990.

[57] C. Tennant, "Work-Related Stress and Depressive Disorders", Journal of Psychosomatic Research, 2001, pp.697-704.

[58] WHO "Facing the Challenges, Building Solutions", in WHO European Ministerial Conference on Mental Health, Helsinki, Finland, January 12-15, 2005.

[59] D. Straub, and E. Karahanna, "Knowledge Worker Communications and Recipient Availability: Toward a Task Closure Explanation of Media Choice", Organization Science, 1998, pp.160-175.

[60] M. Mazmanian, J. Yates, and W. Orlikowski, "Ubiquitous Email: Individual Experiences and Organizational Consequences of Blackberry Use", In Academy of Management Proceedings, Academy of Management, 2006, pp. D1-D6.

[61] C.A. Middleton, and W. Cukier, W., "Is Mobile Email Functional or Dysfunctional? Two Perspectives on Mobile Email Usage", European Journal of Information Systems, 2006, pp. 252-260.

\section{Appendix A: Measurement Instrument}

\begin{tabular}{|c|c|c|}
\hline Construct & Items & Source \\
\hline \multirow[t]{5}{*}{$\begin{array}{l}\text { SNS work } \\
\text { use }\end{array}$} & $\begin{array}{l}\text { I use the [SNS Name] system to post } \\
\text { updates on work projects }\end{array}$ & \multirow{5}{*}{ [41] } \\
\hline & $\begin{array}{l}\text { I use [SNS Name] to arrange } \\
\text { meetings with colleagues about work } \\
\text { projects }\end{array}$ & \\
\hline & $\begin{array}{l}\text { I use [SNS Name] to share } \\
\text { information with colleagues about } \\
\text { organizational objectives, policies } \\
\text { and procedures }\end{array}$ & \\
\hline & $\begin{array}{l}\text { I use [SNS Name] to gain access to } \\
\text { others with expertise in a particular } \\
\text { area }\end{array}$ & \\
\hline & $\begin{array}{l}\text { I use [SNS Name] to share my } \\
\text { expertise in a particular area }\end{array}$ & \\
\hline \multirow[t]{7}{*}{$\begin{array}{l}\text { Positive } \\
\text { emotions }\end{array}$} & $\begin{array}{l}\text { During the past week, how frequently } \\
\text { did you feel each of the following } \\
\text { emotions? } \\
\text { Joy }\end{array}$ & \multirow{7}{*}{$\begin{array}{l}{[42],} \\
{[43]}\end{array}$} \\
\hline & Happiness & \\
\hline & Contentment & \\
\hline & Pride & \\
\hline & Affection & \\
\hline & Love & \\
\hline & Caring & \\
\hline \multirow[t]{3}{*}{$\begin{array}{l}\text { Work } \\
\text { isolation }\end{array}$} & $\begin{array}{l}\text { I am well integrated with the } \\
\text { department/company where I work }\end{array}$ & \multirow{3}{*}{$\begin{array}{l}{[35],} \\
{[36]}\end{array}$} \\
\hline & $\begin{array}{l}\text { I am kept in the loop regarding } \\
\text { company social events/functions }\end{array}$ & \\
\hline & I am part of the company network & \\
\hline \multirow{3}{*}{$\begin{array}{l}\text { Job } \\
\text { Satisfaction }\end{array}$} & All in all, I am satisfied with my job & \multirow{3}{*}{$\begin{array}{l}{[46]} \\
{[47]}\end{array}$} \\
\hline & I am pleased with my current job & \\
\hline & I am happy with my current job & \\
\hline Turnover & $\begin{array}{l}\text { How often have you seriously } \\
\text { considered quitting your present job? }\end{array}$ & [47] \\
\hline \multirow[t]{6}{*}{ Stress } & $\begin{array}{l}\text { Please indicate the extent to which } \\
\text { the following words describe your } \\
\text { job: }\end{array}$ & \multirow{6}{*}{$\begin{array}{l}{[44],} \\
{[45]}\end{array}$} \\
\hline & Demanding & \\
\hline & Pressured & \\
\hline & Hectic & \\
\hline & Many things stressful & \\
\hline & Pushed & \\
\hline
\end{tabular}

